\title{
The growing pains of biodefense
}

Anthony Fauci, Director of the National Institute of Allergy and Infectious Diseases (NIAID), is one among many who hope that Congress will have authorized President Bush's Project Bioshield by the time you read this issue of the JCI. This initiative will provide $\$ 5.6$ billion over the next decade for the development and procurement of treatments and vaccines that can be used in the event of biological warfare. It will also relieve the pressure on Fauci and the NIAID, which have so far carried the weight of America's desire to build biological defenses against all known pathogens of terror.

The biodefense program has moved quickly. Within 12 months of the terrorist attacks of September 11, 2001, which were swiftly

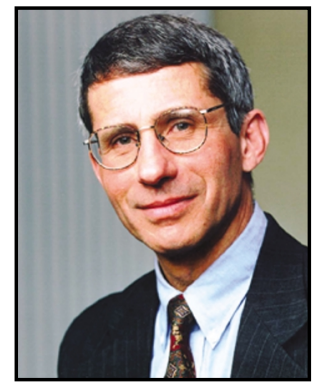

Anthony Fauci: Balancing NIAID's budgets. followed by a national anthrax emergency, NIAID convened a meeting of interested scientists to announce details of the huge federal budget on offer for biodefense research through their institute. Virtually overnight, \$1.7 billion - the amount it has taken the field of AIDS research over 20 years to amass - became available for biodefense research. However, spending this much money on what is in essence a new area of research and integrating this new science into the NIH research program has not proven easy.

\section{Borrowing budget money}

Given the scale of funding available, it is ironic that Fauci's most recent problem has been his need to obtain increased funding for biodefense research from the pockets of the traditional, infectious disease programs. In order to advance the development of an anthrax vaccine as directed by the Office of Management and Budget (OMB), he has diverted \$233 million from existing NIAID grants to secure stocks of recombinant protective antigen from the biotech companies Avecia and Acambis.
This transfer has infuriated many, particularly the most vocal sector of the scientific community, AIDS researchers, who succeeded in persuading Congressman Henry Waxman and Senator Jeff Bingaman to petition Congress to reverse the decision. Their letter of July 11 states that "preparing for a possible anthrax attack cannot be done at the expense of dealing with very real public health threats, such as West Nile Virus, SARS, HIV/AIDS, or a new emerging infectious disease."

HIV expert Mario Stevenson, from the University of Massachusetts Medical Center, told the JCI, "Almost everyone who has a grant funded by NIAID is affected by this. Effectively, the duration of the award will be reduced, which also means that rec-

agency should stick to what it knows best - basic research. Fauci explains that he struck an agreement with the the OMB to add an extra $\$ 250$ million to the NIAID budget to purchase vaccine doses. But when the budget hit Congress, it insisted that NIH should not be involved in procurement and withdrew the sum of money, without, Fauci says, designating it as having been removed from the anthrax program.

"You can see where this left me with an unfunded mandate," he says. "So I worked out a way to have the least negative impact on the grantees. OMB agreed that we could spread the $\$ 250$ million (later recalculated to $\$ 233$ million) over two years - FY03 and FY04. So for FY03 we decided that half the money would come out of the biodefense budget and half out of the split between AIDS, non-AIDS, and non-biodefense. We could either decrease the number of grants, cut the amount of grants, or readjust the cycle, recycle if you like, certain grants. In 04 , all the money will come out of biodefense. Then when Bioshield comes into effect, this will deal with all procurement."

Recycling has meant that projects funded in FY03 have been truncated by six months, converting five year grants to 4.5 years and four year grants to 3.5 year grants. But at odds with Fauci's insistence that taking money away from grantees won't happen again, AIDS researchers claim that the precedent was set in 2002. Doug Richman, Director of the Center for AIDS Research at UC San the advance development Mario Stevenson: Less time to spend less money. teed. They took the unusual step of giving NIAID the responsibility of paying to

Diego, told the JCI he had to close his and obtain[ing] 25 million doses of anthrax costing around \$250 million,” he told the JCI.

Until now, the NIH has never been involved in the procurement of medicines. Its foray into this activity is another factor that many scientists are unhappy about as they insist that the center for a period last year due to "recycling" of funds. "The explanations were never sufficiently clear to distinguish between administrative callousness and thriftiness. I think it's fair to say that there is a lack of transparency to the administration of the 
funding for biodefense and what adjustments are coming out of the hide of other programs."

\section{The rush to fund}

In the broader research community, there has been concern that the risk in hurriedly throwing money at a new field is that much of it will be wasted because of inexperience, both that of the grant selectors and of the recipients. Questions have been raised as to what proportion of scientists receiving biodefense grants have significant experience in working with priority pathogens, and only time can tell how productive each project will be.

Ariella Rosengard, from the University of Pennsylvania, is a scientist with experience in this field who was both shocked and perplexed to find that she was-
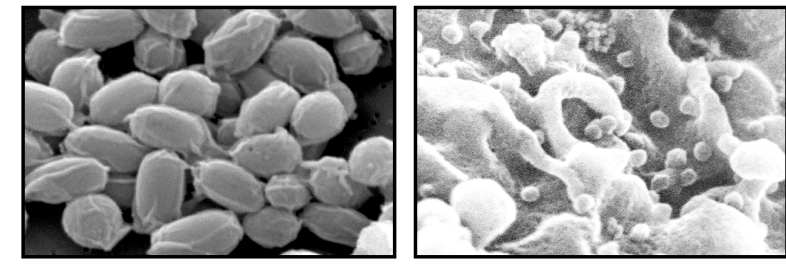

Which is the bigger threat? Anthrax (left) or HIV (right)? Photo credit: Anthrax (left), Janice Carr; HIV (right), C. Goldsmith, Centers for Disease Control. n't to be given a dime from the hefty biodefense coffers. As one of only two US-based researchers known to have worked on true variola protein before September 11, Rosengard felt confident that she could contribute to the effort with her reagents and data on the variola regulator, smallpox inhibitor of complement enzymes (SPICE). But her application was rejected.

Perhaps, says Rosengard, the review body didn't understand the significance of her work. SPICE has proven 100 -fold more potent than virus complement control protein at inactivating the hub of the human complement cascade, C3b. As such, understanding the high efficiency of inactivation of the human complement of this regulator could be key to learning why smallpox is restricted to human hosts and how it evades the immune system. "The US government claims they're in a race against terror. This isn't an academic exercise. I have reagents and data," says Rosengard. Although not deemed valuable enough to be part of the national defense effort, her variola regulator detection technique and nine monoclonal antibodies are attracting attention from private companies.

Some scientists who have received biodefense money do have a track record in working with priority pathogens. Alex Strongin, of the Cancer Research Center at the Burnham Institute, is heading a team working on inhibitors of anthrax lethal factor (LF) for human use. Over the past five years, team member Robert Liddington has identified the atomic structure of LF and the protective antigen of anthrax. Strongin says, "You'll see that this is not all about money. The funding is only $\$ 580,000 /$ direct cost/annually for all of us. The grant duration is 3.5

tion claims that a "consistently strong spirit of cooperation among traditionally competing institutions has established an interlocking network of projects." Walker says many members of the consortium have experience in working with priority pathogens. Speaking in regard to anthrax, viral hemorrhagic fevers, rickettsiae, brucellosis, Q fever, tularemia, and flaviviruses, he told the $J C I$ that "although there may be greater expertise with one or two of these agents in other centers, I believe that we have more overall experience than anyone with priority pathogens hundreds of person-years."

While not yet confirmed, projections have been made that the budget for Region VI will be $\$ 48$ million over 4.5 years. Walker does have confirmation of $\$ 4.25$ million for the initial six months. He says, "NIH budgetary issues may lie

years. We asked for five years, the study section gave us four, and the funding mechanisms at NIAID deleted an additional 0.5 due to a program cut. This is not a free giveaway party."

\section{A defense network}

Expertise is also to be found in the eight Regional Centers of Excellence (RCE's) for Biodefense and Emerging Infectious Disease Research that were announced in September. These newly organized multi-institutional consortia are intended to form a network of biodefense expertise in basic research, drug and vaccine development, and medical training across the US. They will be headquartered in offices at Duke, Chicago, Maryland and Washington Universities, Harvard Medical School, the New York State Department of Health, the University of Texas Medical Branch, and Washington University in St. Louis. A California base is conspicuously lacking.

David Walker, Professor and Chairman of the Department of Pathology at the University of Texas Medical Branch, is leading Region VI RCE, which comprises 22 institutions in Texas, New Mexico, Oklahoma, Arkansas, and Louisiana. The Region's grant applica- behind the funding. These grants are all being 'recycled,' the NIH term for a short first year. I believe that this is the general approach for all RCEs."

Meanwhile, Alfred Sommer, Dean of the Bloomberg School of Public Health, offers a long-term, pragmatic perspective on the rush to create a biodefense research field. "There's nothing like a hanging to focus the mind," he says. "By making lots of money available, it will draw lots of folks to the party. Many of these will ultimately fall by the wayside, having contributed little; but some bright folks will decide to enter the arena and make this their career. It will be a magnet to draw good people in."

Even if views of how the initiative is being handled differ at this early stage, there is general appreciation among the biomedical community that the government has identified a large void in the country's defenses against which it needs to take action, partly by creating a large research enterprise. As Sommer observes, "This strategy resonates with the public and is not unlike the 1950's 'war on cancer,' which has resulted in tectonic movements in knowledge and application, even if cancer is not yet conquered." 